\title{
Foundations' Share of Private Philanthropy
}

\section{Sources of Private Contributions}

- Individuals provide more than four-fifths of private contributions

- Foundations account for highest share of private contributions since 1970

- Excluding giving for religion, foundations account for close to one-fifth of private contributions

Given the large number of foundations, and the attention paid to a few highly visible grantmaker programs, grantseekers and journalists often overestimate the role that foundations play in the nonprofit sector. In fact, foundation giving represents a modest portion of all private contributions, which in turn account for a relatively small percentage of the overall income of America's nonprofits.

According to estimates published in Giving USA, private contributions from all sources totaled $\$ 157.7$ billion in 1997 (Figure 14 and Table 55), representing 2.0 percent of the gross domestic product. ${ }^{1}$ The largest portion of these contributions- $\$ 135.6$ billion or 86.0 percent-came from individual donors either through gifts (78.0 percent) or bequests (8.0 percent). Independent, community, and grantmaking operating foundations were responsible for another 8.8 percent of total estimated private giving - the highest share reported since 1970 - while the remaining 5.2 percent came from corporations and corporate foundations. (If corporate foundation grant dollars are added to those of other foundations, the share rises to 10.1 percent for foundations.)

1. Kaplan, A. Giving USA: The Annual Report on Philanthropy for the Year 1998. New York: AAFRC Trust for Philanthropy, 1999.
FIGURE 14. Distribution of Private Philanthropic Giving, 1997

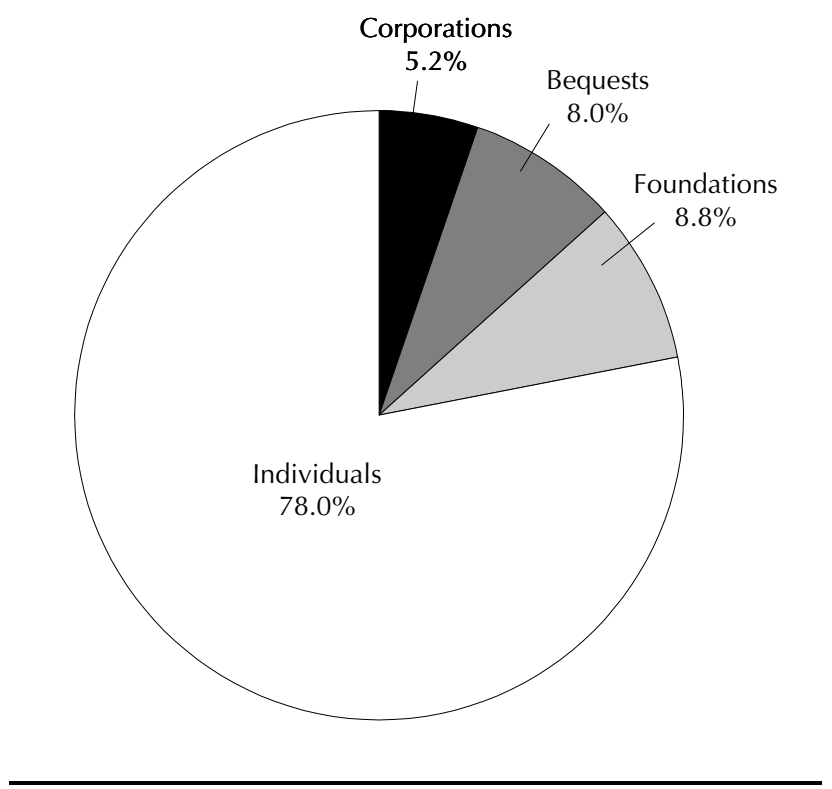

Source: Giving USA, New York: AAFRC Trust for Philanthropy, 1999.

Non-foundation figures for 1997 were estimated.

Corporate data include corporate foundation giving.

TABLE 55. 1997 Private Philanthropic Giving (Dollars in billions)

\begin{tabular}{lrr} 
Source & Amount & $\%$ \\
\hline Individuals & $\$ 123.0$ & 78.0 \\
Bequests & 12.6 & 8.0 \\
Independent and Community Foundations & 13.9 & 8.8 \\
Corporations/Corporate Foundations & 8.2 & 5.2 \\
$\quad$ Total & $\mathbf{\$ 1 5 7 . 7}$ & $\mathbf{1 0 0 . 0}$ \\
\hline
\end{tabular}

Source: Giving USA, New York: AAFRC Trust for Philanthropy, 1999.

Non-foundation figures for 1997 were estimated.

${ }^{1}$ Of total corporate giving for 1997, $\$ 2.1$ billion (25.6\%) was paid through corporate foundations (see Table 2). 
Individuals thus provide the vast majority of philanthropic donations, more than six times that provided by foundations and businesses combined. Yet these proportions are somewhat misleading. It bears noting that just over three-fifths of giving from individuals is for the benefit of religious congregations, primarily, although far from exclusively, for sacramental purposes. Consequently, if religion is excluded from the private giving denominator, foundations' and corporations' share of support for the nonprofit public-benefit service sector increases significantly. ${ }^{2}$

For example, Giving USA estimates that 46.1 percent of private contributions in $1997-\$ 72.7$ billion-went to religion, most of it in gifts from individuals to their congregations. If religion is excluded, then private and community foundations' share of the remaining $\$ 85.0$ billion in contributions jumps to 18.8 percent. While still relatively modest, this proportion nevertheless presents a far more accurate measure of all U.S. foun-

2. Salamon, L. America's Nonprofit Sector: A Primer. New York: Foundation Center, 1992. Revised edition published in 1999. dation support as a percent of overall private funding in the fields in which they are most active (e.g., education, human services, health, and the arts).

Foundation giving as a proportion of the whole philanthropic pie grew rapidly during the 1960s and then reached a peak in 1970 (Table 56). Throughout the 1970s, restrictive government regulations, inflation, and a shrinking asset base (factors discussed in earlier chapters) effectively reduced the role of foundations. With the easing of some restrictions in the 1980s, and a soaring stock market raising foundation assets, foundation giving as a share of private contributions inched back up and continued to rise in the 1990s. In 1997, the share of giving totaled 8.8 percent, up from 8.7 percent in 1996 and approaching the record 9.0 percent share reported in 1970.

Corporate contributions, including corporate foundation giving, grew quickly between 1970 and 1980, although not as rapidly as individual giving. As a percent of all U.S. philanthropy, corporate giving peaked in the mid-1980s at 6.5 percent, and then gradually declined. In 1991, its share dipped to 5.0 percent. The continued downsizing of companies, deep losses in

TABLE 56. Percentage of Private Philanthropic Giving by Source, 1965-1997 (Dollars in billions)

\begin{tabular}{|c|c|c|c|c|c|c|c|c|}
\hline \multirow[b]{2}{*}{ Year } & \multicolumn{2}{|c|}{ Total Giving } & \multicolumn{2}{|c|}{$\begin{array}{c}\text { Independent \& } \\
\text { Community Fdns. }\end{array}$} & \multicolumn{2}{|c|}{$\begin{array}{l}\text { Corporations/ } \\
\text { Corporate Fdns. }\end{array}$} & \multicolumn{2}{|c|}{$\begin{array}{l}\text { Individuals/ } \\
\text { Bequests }\end{array}$} \\
\hline & Amount & $\%$ & Amount & $\%$ & Amount & $\%$ & Amount & $\%$ \\
\hline 1965 & 14.71 & 100.0 & 1.13 & 7.7 & 0.74 & 5.0 & 12.84 & 87.3 \\
\hline 1966 & 15.79 & 100.0 & 1.25 & 7.9 & 0.79 & 5.0 & 13.75 & 87.1 \\
\hline 1967 & 17.03 & 100.0 & 1.40 & 8.2 & 0.82 & 4.8 & 14.81 & 87.0 \\
\hline 1968 & 18.85 & 100.0 & 1.60 & 8.5 & 0.90 & 4.8 & 16.35 & 86.7 \\
\hline 1969 & 20.66 & 100.0 & 1.80 & 8.7 & 0.93 & 4.5 & 17.93 & 86.8 \\
\hline 1970 & 21.04 & 100.0 & 1.90 & 9.0 & 0.82 & 3.9 & 18.32 & 87.1 \\
\hline 1971 & 23.44 & 100.0 & 1.95 & 8.3 & 0.85 & 3.6 & 20.64 & 88.1 \\
\hline 1972 & 24.44 & 100.0 & 2.00 & 8.2 & 0.97 & 4.0 & 21.47 & 87.8 \\
\hline 1973 & 25.59 & 100.0 & 2.00 & 7.8 & 1.06 & 4.1 & 22.53 & 88.0 \\
\hline 1974 & 26.88 & 100.0 & 2.11 & 7.8 & 1.10 & 4.1 & 23.67 & 88.1 \\
\hline 1975 & 28.56 & 100.0 & 1.65 & 5.8 & 1.15 & 4.0 & 25.76 & 90.2 \\
\hline 1976 & 31.85 & 100.0 & 1.90 & 6.0 & 1.33 & 4.2 & 28.62 & 89.9 \\
\hline 1977 & 35.21 & 100.0 & 2.00 & 5.7 & 1.54 & 4.4 & 31.67 & 89.9 \\
\hline 1978 & 38.57 & 100.0 & 2.17 & 5.6 & 1.70 & 4.4 & 34.70 & 90.0 \\
\hline 1979 & 43.11 & 100.0 & 2.24 & 5.2 & 2.05 & 4.8 & 38.82 & 90.0 \\
\hline 1980 & 48.63 & 100.0 & 2.81 & 5.8 & 2.25 & 4.6 & 43.57 & 89.6 \\
\hline 1981 & 55.28 & 100.0 & 3.07 & 5.6 & 2.64 & 4.8 & 49.57 & 89.7 \\
\hline 1982 & 59.11 & 100.0 & 3.16 & 5.3 & 3.11 & 5.3 & 52.84 & 89.4 \\
\hline 1983 & 63.21 & 100.0 & 3.60 & 5.7 & 3.67 & 5.8 & 55.94 & 88.5 \\
\hline 1984 & 68.58 & 100.0 & 3.95 & 5.8 & 4.13 & 6.0 & 60.50 & 88.2 \\
\hline 1985 & 71.69 & 100.0 & 4.90 & 6.8 & 4.63 & 6.5 & 62.16 & 86.7 \\
\hline 1986 & 83.25 & 100.0 & 5.43 & 6.5 & 5.03 & 6.0 & 72.79 & 87.4 \\
\hline 1987 & 82.21 & 100.0 & 5.88 & 7.2 & 5.21 & 6.3 & 71.11 & 86.5 \\
\hline 1988 & 88.04 & 100.0 & 6.15 & 7.0 & 5.34 & 6.1 & 76.55 & 86.9 \\
\hline 1989 & 98.43 & 100.0 & 6.55 & 6.7 & 5.46 & 5.5 & 86.42 & 87.8 \\
\hline 1990 & 101.37 & 100.0 & 7.23 & 7.1 & 5.46 & 5.4 & 88.68 & 87.5 \\
\hline 1991 & 105.01 & 100.0 & 7.72 & 7.4 & 5.25 & 5.0 & 92.05 & 87.7 \\
\hline 1992 & 110.41 & 100.0 & 8.64 & 7.8 & 5.91 & 5.4 & 95.85 & 86.8 \\
\hline 1993 & 116.54 & 100.0 & 9.53 & 8.2 & 6.47 & 5.6 & 100.54 & 86.3 \\
\hline 1994 & 119.17 & 100.0 & 9.66 & 8.1 & 6.98 & 5.9 & 102.53 & 86.0 \\
\hline 1995 & 123.98 & 100.0 & 10.56 & 8.5 & 7.32 & 5.9 & 106.09 & 85.6 \\
\hline 1996 & 138.64 & 100.0 & 12.00 & 8.7 & 7.51 & 5.4 & 119.13 & 85.9 \\
\hline 1997 & 157.69 & 100.0 & 13.91 & 8.8 & 8.20 & 5.2 & 135.58 & 86.0 \\
\hline
\end{tabular}


some industries during the recession of the early 1990s, and continued challenges to corporate giving (often deemed by stockholders as too controversial or outside of the company's interests) pointed to a reduced role for business in American philanthropy. While support offered through corporate giving programs and corporate foundations has grown in the 1990s (see Corporate Foundations, Chapter 2), the growth has not matched increases reported by noncorporate foundations and individuals. Moreover, an increasing number of corporations are channeling their charitable support through corporate sponsorships and other forms of corporate marketing, which are not reflected in figures for charitable giving. As a result, in 1997 corporate contributions dipped to 5.2 percent of philanthropic giving, down from 5.4 percent in 1996 and the 5.9 percent share reported in the two preceding years.

\section{Funding Nonprofit Agencies: Private Giving as One Source of Income}

- Private contributions account for less than one-fifth of nonprofits' income

- Private support most important for arts and civic affairs organizations

- Government targets its largest shares to social service and health organizations

- Importance of earned income grows across the nonprofit sector

The discussion above focused on the relative importance of the various sources of private income and showed that U.S. grantmaking foundations represent a modest share of all private giving - between 10 and nearly 19 percent-depending on whether religious giving is included in the giving base. What follows is an assessment of the role private giving itself plays as one source of annual funds for nonprofits.

Nonprofit income in 1996, including church revenues, was estimated at $\$ 621.4$ billion, up 22 percent from $1992 .{ }^{3}$ Of that total, less than one-fifth (18.9 percent) came from private contributions, compared to nearly one-half (49.4 percent) from earned income, including fees and other charges for services, income from endowments, and other receipts. The final onethird (31.7 percent) came from federal, state, and local governments (Table 57).

Income from private contributions as a share of nonprofit revenue has shrunk dramatically. Between 1977 and 1996, the share of annual revenue from private contributions dropped from 26.3 percent to 18.9 percent (a nearly 28 percent loss). ${ }^{4}$ Over the same period, the share provided by the government sector jumped from 26.6 percent to 31.7 percent; and the proportion from dues, fees, and charges and from endowment and other receipts also grew, from 47.3 percent to 49.4 percent.

A sharp drop in income from private contributions as a proportion of all revenue occurred between 1977 and 1982, followed by a period of relative stability in the mid-1980s. The share dropped again between 1987 and 1992, from 22.9 percent to 18.4 percent, and increased only slightly during the most recent period. While revenue from government sources declined during the early Reagan years, it grew from 27.9 percent to 31.3 between 1987 and 1992 and inched up to 31.7 percent in 1996. Earned income, endowments, and other receipts grew slightly from 1987 to 1992

3. Hodgkinson, $\mathrm{V}$., et al. "The State of the Independent Sector: Overview and Highlights." Washington, DC: INDEPENDENT SECTOR, 1998.

4. Hodgkinson, V., et al. Nonprofit Almanac: Dimensions of the Independent Sector 1996-1997. Washington, DC: National Center for Charitable Statistics, INDEPENDENT SECTOR, 1996.

TABLE 57. Percentage Distribution of Annual Sources of Support for Independent Sector Organizations, 1996

\begin{tabular}{|c|c|c|c|c|c|c|c|c|}
\hline \multirow[b]{2}{*}{ Sources of Funds } & \multicolumn{2}{|c|}{ All Independent Sector } & \multirow{2}{*}{$\begin{array}{l}\text { Civic } \\
\text { Affairs }\end{array}$} & \multirow{2}{*}{$\begin{array}{c}\text { Arts/ } \\
\text { Culture }\end{array}$} & \multirow{2}{*}{$\begin{array}{l}\text { Health } \\
\text { Services }\end{array}$} & \multirow{2}{*}{$\begin{array}{l}\text { Education/ } \\
\text { Research }\end{array}$} & \multirow{2}{*}{$\begin{array}{c}\text { Social } \\
\text { Services }\end{array}$} & \multirow{2}{*}{$\begin{array}{c}\text { Religious } \\
\text { Organizations }\end{array}$} \\
\hline & Dollars* & $\%$ & & & & & & \\
\hline Government Sector & $\$ 196.8$ & 31.7 & 30.2 & 14.3 & 41.0 & 19.6 & 53.4 & \\
\hline Private Contributions & 117.5 & 18.9 & 35.2 & 40.0 & 3.6 & 12.7 & 19.9 & 96.5 \\
\hline Dues, Fees, Charges & 239.7 & 38.6 & 20.7 & 23.8 & 47.9 & 56.5 & 17.9 & 7.4 \\
\hline Endowments & 31.5 & 5.1 & 6.1 & 9.5 & 2.2 & 5.9 & 2.4 & 3.1 \\
\hline Other Receipts ${ }^{1}$ & 35.9 & 5.8 & 7.8 & 12.4 & 5.3 & 5.3 & 6.3 & $(7.0)$ \\
\hline Total & $\$ 621.4$ & 100.0 & 100.0 & 100.0 & 100.0 & 100.0 & 100.0 & 100.0 \\
\hline
\end{tabular}

SOurCe: INDEPENDENT SECTOR, 1998

*Due to rounding, percentages may not total 100.0.

${ }^{1}$ Other Receipts includes church receipts. Due to expenditures by religious organizations, their net Other Receipts is less than zero. 
from 49.2 percent to 50.2 percent-then fell back to 49.4 percent in 1996.

The proportion of annual income-both operating and capital-derived from these major sources of revenue differed widely by sector. For example, private donations in 1996 accounted for less than 4 percent of health agencies' income, nearly 13 percent for educational organizations, 20 percent for social service agencies, 35 percent for civic affairs organizations, and 40 percent for arts organizations. In the arts subsector, however, the high proportion of private contributions as a percent of income included gifts of expensive art objects donated at current market value to museums and other large capital gifts. If those gifts were excluded, private donations would represent a smaller share of income.

Like private giving, earned income also varied as a percent of overall revenue by subsector, although the differences were less dramatic. Not surprisingly, educational institutions and health service organizations derived by far the largest share of their revenue -68 percent and 55 percent, respectively - from dues, fees, and charges, endowment income, and other receipts. Earned income also provided 46 percent of the total revenue of arts groups and 27 percent of the total revenue of social service agencies.

Finally, the government sector remained a key source of annual funds for some segments of nonprofits, but a minor source for others. In 1996, federal, state, and local governments distributed more than half of the funds in the social and legal services field; twofifths of the income in the health services sector; threetenths in civic affairs; one-fifth in education and research; and only one-seventh in arts and culture.

\section{Sources of Income by Subsector, 1977-1996}

With regard to changes between 1977 and 1996 by source of income and by subsector, private contributions as a share of overall revenue dropped most sharply in health services; in education, the share increased sharply through the 1980s, and then stayed constant in the 1990s; in social services, it has declined continuously through the 1980s and into the 1990s; in civic affairs, it increased rapidly in the mid-1980s, declined from 1987 to 1992, but rebounded through 1996; and in the arts it remained nearly stable.

By comparison, the proportion of earned income as a percent of annual revenue increased across most subsectors during this period. The shift toward greater emphasis on fee-for-service activities was most apparent in the social and legal services sector, where revenues from fees and other receipts jumped from less than 14 percent to nearly 27 percent. Similar growth occurred in civic affairs and, to a lesser extent, in the arts field. Conversely, the share of total revenue from earned income in the education and health sectors declined through the 1980s, but has remained roughly constant in the most recent period.

Finally, changes in levels of government support of the nonprofit sector reveal the widest discrepancies. For example, despite the widely reported federal budget cuts of the early 1980s, government spending for health services increased through 1987 and continued to climb in the 1990s. Fueled by escalating health costs and the needs of an aging population, government's share of annual funds for the health sector rose from 32 percent in 1977 to 41 percent in 1996. Though far less dramatic in scale, government support for education also grew, from 18.2 percent to 20 percent, but only after 1987. In contrast, government support for the arts grew rapidly through 1982, but declined in the years following. Nevertheless, government funding as a share of all arts income was higher in 1996 (14.3 percent) than in 1977 (11.8 percent).

During the 1980s, government severely reduced its commitment to two sectors: civic affairs and social and legal services. In the 1990s, government support increased for one area, while it fell for the other. Government spending as a percent of overall income dropped dramatically in the civic affairs area, from one-half in 1977 to just three-tenths in 1996. In this sector, earned income as a share of all income has nearly doubled over the same period, while private contributions have also grown. In the social and legal services area, government supplied 54 percent of the annual funds of that sector in 1977. By 1987, this share declined to only 48 percent. The share has since rebounded to 53 percent in 1996. Despite the reduction in government support, considerable growth occurred in the social services field in the 1980s both in the number of agencies and in overall employment. Much of that growth was paid for by increases in fees for services and other receipts.

\section{The Role of Private Philanthropy in the 1980s}

- Growth in private giving lags behind other
sources of nonprofit income

- Decentralized nonprofit sector reinforces inequalities created by government cutbacks

Reductions in government social welfare spending, both directly through cuts in income assistance programs and through diminished support for nonprofit 
social service providers, have focused increased attention on private philanthropy. Although there was evidence of significant gains in private giving in the 1980s, it is clear that these increases could not match the growing needs of the sector caused by the escalating costs of delivering health services, rising poverty, and other social problems.

In his primer on America's nonprofits, economist Lester Salamon charted the overall growth of the nonprofit sector in the 1980s and identified shifts in sources of support. Between 1977 and 1989, he noted, the sector grew by 79 percent, after adjusting for inflation, with growth in the health area outpacing all other subsectors. In contrast, Salamon observed, "The hoped for surge in private, charitable support did not occur. Although private giving did grow, by about 53 percent in inflation-adjusted terms, its growth lagged behind that of most of the other sources of nonprofit income." ${ }^{5}$ Thus, over that twelve-year period, private giving accounted for only 15 percent of the overall growth of the nonprofit sector.

Instead of private giving, he noted, the major sources of nonprofit growth during the 1980s were service fees and other commercial income, which accounted for over half of new growth. Finally, nonprofit receipts from government continued to grow, although concentrated almost entirely in the health field.

The implication for private philanthropy, and for foundations as one source of philanthropy, was a slightly diminished role in the larger sphere of the charitable sector. Yet what in fact resulted, especially among nonprofits most affected by government retrenchment, was the evolution of an even more competitive fundraising market as these organizations were forced to explore all possible sources of support and revenue.

The marketization of charities in the pursuit of earned income and stepped-up competition for private support were not the only consequences of government retrenchment in the 1980s. In his 1993 book exploring the relationship of the nonprofit sector with the private and public sectors, Julian Wolpert argued that the devolution and decentralization of federal programs has produced considerable disparity in quality of life and access to key services between geographic areas, since states and cities vary in their resources and willingness to compensate for federal cutbacks. ${ }^{6}$ Moreover, a decentralized system of charities, which provide services almost uniquely to their

\footnotetext{
5. Salamon, 1992

6. Wolpert, J. Patterns of Generosity in America: Who's Holding the Safety Net? New York: The Twentieth Century Fund Press, 1993.
}

own communities and local donors, has reinforced rather than compensated for these inequities. "Public and private generosity stem more from the presence of prosperity than distress and tend to operate in tandem rather than as substitutes," he observes. In short, even if private contributions increased significantly, they would benefit areas where affluence is greater, leaving large holes in the safety net in those areas where distress is greater. The fragmentation of the nonprofit sector only confirms that it is the federal government that is best suited to maintaining safety nets. "Pockets of local distress should not rely purely upon local resources and generosity of spirit," Wolpert concludes.

\section{The 1990s: Private Philanthropy in an Era of Government Devolution}

- Government support for nonprofits declines

- Growth in private giving unlikely to compensate
for government cuts

An analysis of funding patterns of the nonprofit sector from 1987 to 1992 reveals that state governments were able to partially offset the impact of federal government cuts pursued by the Reagan Administration in the early 1980s. Yet, starting in 1994, with the election of a Republican majority in Congress, a full scale campaign toward government devolution was mounted in Washington-supported by a majority of Republican governors across the country. Federal budget proposals approved by Congress in 1995/1996 have led to deep reductions in federal funding - and in several cases the elimination of entire government programs-affecting nearly all areas of the voluntary sector. More recently, the Balanced Budget Act of 1997, which was first approved by Congress and then signed into law by President Clinton, called for steep cuts in federal spending in areas of interest to the nonprofit sector. The plan is being implemented in a multi-step process and will end with a consistently balanced federal budget by 2002 .

In a 1997 report prepared for Independent Sector, authors Alan Abramson and Lester Salamon estimated the impact of federal spending cuts from 1995 to 2002 on areas of broad concern to nonprofits (international affairs, community development, education and social services, health, Medicare, and income assistance). ${ }^{7}$ Based on Congressional projections of 1997

\footnotetext{
7. Abramson, A. and Salamon, L. "The Nonprofit Sector and the Federal Budget: Update as of September 1997." Washington, DC: INDEPENDENT SECTOR, 1997.
} 
federal spending, the study concludes that between 1995 and 1997, spending in areas of primary interest to nonprofits fell in nearly every area except income security and health (where automatic entitlement formulas drive spending), and community and regional development (where current funding levels nevertheless remain below those in 1980). Funding for education, training, employment and social services fell by $\$ 5.9$ billion or 11 percent, while support for international affairs and development fell $\$ 2.5$ billion or 15 percent. Moreover, over the same two-year period, direct federal support of nonprofits is estimated to have decreased $\$ 1.3$ billion (1 percent). Excluding health, federal support to nonprofits declined a much larger 10 percent. The sharpest declines were in international aid (20 percent), and in education, training, employment, and social services (11 percent).

Federal spending cuts affecting nonprofits are expected to be even more severe by 2002. Abramson and Salamon estimate that federal outlays in areas of concern to nonprofits will drop $\$ 12.4$ billion (2 percent) overall between 1995 and 2002. With income assistance excluded, spending will decline by $\$ 32.7$ billion (9 percent) from 1995 levels. Among the areas to be affected, federal support is predicted to fall $\$ 3.5$ billion (33 percent) in community and regional development, $\$ 3.9$ billion (24 percent) in international assistance, $\$ 23.6$ billion ( 9 percent) in health, and $\$ 1.7$ billion ( 3 percent) in education. Direct support of nonprofits is expected to fall $\$ 11.9$ billion (9 percent) during this period.

Implications for Private Giving. The authors predict that because the budget resolutions are phased in over a number of years, projected increases in private giving will be adequate to sustain the income needs of nonprofits through 2001. They warn, however, that starting in 2002, when the full impact of federal budget cuts is felt by nonprofits, private giving will be unable to make up the huge losses in income caused by these cuts. To offset cuts in direct federal support of nonprofits proposed for 2002, private giving would have would have to increase by an additional 9 percent in real value on top of a projected annual 3 percent increase. In other words, private giving would have to grow at a rate three times greater than its recent highs.

Given what is already known about the historical growth patterns of charitable giving, it is highly unlikely that private giving will grow fast enough to meet these daunting challenges. Nevertheless, foundations, corporations, and other private donors will have to seek ways to maximize their impact through contributions and other forms of support. The following chapter, "Trends in Giving," examines foundations' responses to stepped up demands for contributions in the 1980s and 1990s. 